\title{
Antioxidant Activity of Some Fluids Extracts of Indigenous Wild Cherry Fruits
}

\author{
Bogdan Ștefan Negreanu-Pîrjol \\ "Ovidius" University of Constanta, Faculty of \\ Pharmacy, Constanta, Romania \\ Emin Cadâr \\ "Ovidius" University of Constanta, Faculty of \\ Pharmacy, Constanta, Romania \\ Rodica Sîrbu \\ "Ovidius" University of Constanta, Faculty of \\ Pharmacy, Constanta, Romania \\ Ticuța Negreanu-Pîrjol \\ "Ovidius" University of Constanta, Faculty of \\ Pharmacy, Romania
}

\begin{abstract}
The paper presents un study regarding the comparative total antioxidant capacity of some fluids extracts of the soluble lipid compounds of Cerasus avium (L.) Moench. syn. Prunus avium (L.) var. sylvestris Ser fruits, popular named wild cherry, species undertaken aiming at exploiting the nutrient profiles and promoting the further development of these indigen phytopharmaceutical resources. For analysis, the photo-chemiluminescence method, ACL procedure, Analytik Jena AG, by comparing with the standard Trolox® solution, was used. Wild cherry fruits fluid extracts analyzed emphasize an increased total antioxidative capacity which may be attributed to the high level content of polyphenolic compounds and minerals content which sustains the possibility to use this valuable vegetal product for nutraceutical or comeceutical preparations.
\end{abstract}

Keywords: wild cherry, fruits, fluid extract, total antioxidant activity 


\section{Introduction}

The name of the plant Cerasus avium (L.) Moench. syn. Prunus avium (L.), popular known as wild cherry or bitter cherry, derives from the city name Cerasus on the shores of the Black Sea in Asia Minor (today Kerasun), from where the plant, in 74 BC, was brought to Europe by Locullus. Was also the name of the cherry at Columella indigenous tree, microphanerophyte - megaphanerophyte, spontaneous and cultivated, with food, industrial, medicinal importance. Phytocenological, wild variety, Carpinion, Querco-Beech, widespread in Europe, Asia Minor, North Africa, the Caucasus Mountains, Turkmenistan, from where it spread to all continents. The cherry (Cerasus avium) has the following varieties: sylvestris Ser., wild cherry, with small fruits, up to $1 \mathrm{~cm}$ in diameter, black, slightly juicy, sweet-bitter and early ripening; juliana (L.) Pojarkova, ispas cherries, with medium fruits, soft pulp, early and medium ripening; duracina (L.) Pojarkova, stony cherries, with large fruits, hard, stony pulp, slightly juicy and late ripening. Most of the varieties are derived from these three botanical varieties [1 - 6]. In Romania, wild cherry with the varieties Amar Maxut and Amar Galata [6], are considered in literature as having the center of origin in Northern Moldova, but also it was acclimatised in Dobrudjia.

Numerous studies have proven that vegetal compounds originated from plants or fruits possess a high spectrum of biological activity. However, polyphenolic extracts (e.g. flavonoids, anthocyanin, tannins etc.), despite having excellent in vitro bioactivity, sometime present a decreased action in vivo due to their improper molecular size, resulting in an absorption and bioavailability decreased. Moreover, the efficacy of natural polyphenols depends on preserving the stability, bioactivity and bioavailability of the active compounds $[7,8$,$] .$

Cherry fruits are considered nutritional products for humans. They are consumed fresh, dried or in preparations such as: compote, tea, jams, jams, marmalade, etc. From the fruits are obtained juices, candied fruits, ice cream or various assortments of yogurts, liqueurs or cakes. Fruits contain fiber, water, vitamins A, B1, B2, B3, B5, B6, B9, C, E, carotene, minerals (iron, calcium, phosphorus, chlorine, sulfur, magnesium, potassium), trace elements (zinc, copper, manganese, cobalt) and sugar in the form of levulose which can also be assimilated by diabetics. Cherry tails contain potassium salts, catehic tannins and flavonoids. Also, cherries contain protein, lipids, carbohydrates (of which glucose, fructose, sucrose and pectins). Organic acids are represented by: malic acid, citric acid, chlorogenic acid, ferulic acid, caffeic acid, pcoumaric acid and oxalic acid $[9,10]$. Cherries are powerful antioxidants, being rich in ascorbic acid, nicotinamide, tocopherol, pantothenic acid, pyridoxine, riboflavin, thiamine, as well as small amounts of biotin and folic acid $[11,12]$. The content of mineral substances is relatively increased, such as potassium, phosphorus, calcium, magnesium, fluorine, sodium and zinc were determined in tissue [13, 14]. The anthocyanin content of fruits varies for dark-colored varieties compared with light varieties. All dark-colored varieties contain higher amounts of cyanidin-3-rutinoside 
and cyanidin-3-glucoside and lower amounts of pelargonidin-3-rutinoside than lightcolored varieties [15-18].

Cerasus avium (syn. Prunus avium) Moench. species, wild cherry, are often used in popular medicine most due to its content in polyphenolic acids with great antioxidative capacity mainly useful in anti - inflammatory diseases, hypoglycemic activities, tonic action due to their synergistic action. For medicinal purposes, the fruits stalk are used for the content in flavonoids. The main components of the peduncles are: tannins, catechins, saponins, proanthocyanidols and minerals (potassium salts) [14-18]. Flavones are represented by quercetol, genistein, dihydrovogonin and naringenol [19-23]. Due to its flavonoid, C and E vitamins, oligoelements content known for their antioxidant activity, the raw material expressed as fresh wild cherry fruits, will be studied to establish their antioxidant capacity and therapeutically potential [24-30]. With rich content in vitamins, minerals, polyphenols, carotenoids and many other compounds, Cerasus avium (syn. Prunus avium) Moench. fruits extracts, may be useful as an adjuvant in the treatment or in preventing many diseases which arise from oxidative stress action of free radicals $[31,32]$.

The aim of this paper was to determined the total antioxidant capacity of some fluids extracts of the soluble lipid compounds of Cerasus avium (L.) Moench. syn. Prunus avium (L.) var. sylvestris Ser, wild cherry fruits [33-35], aiming at exploiting the nutrient profiles and promoting the further development of these indigen phytopharmaceutical resources in some new nutraceuticals, in order to promote their phyto-therapeutic potential in hepato-digestive disorders [36-37].
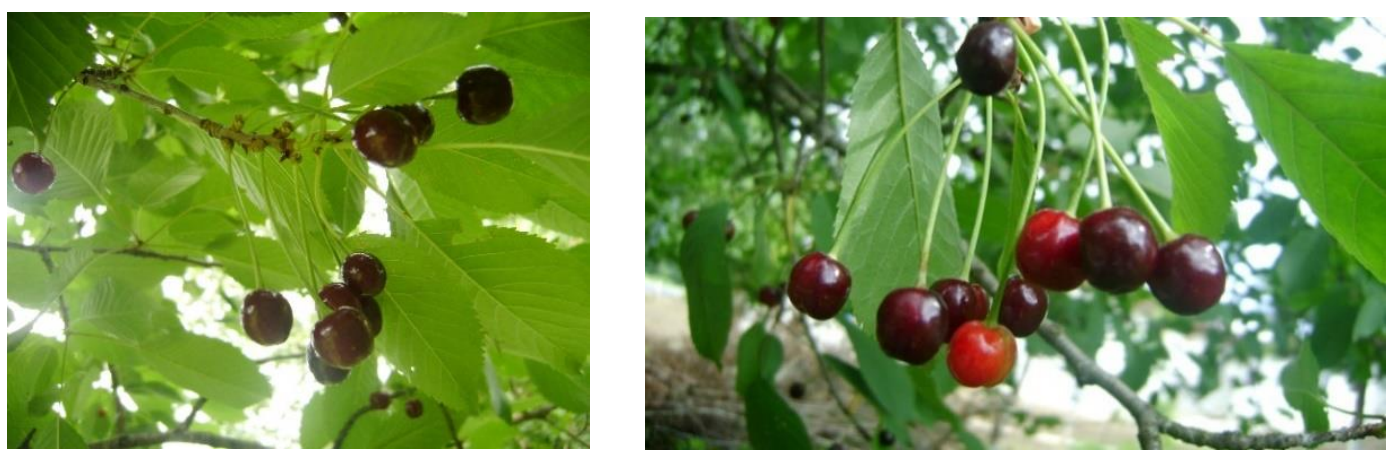

Figure. 1. Cerasus avium (L). Moench. syn. Prunus avium (L.) var. sylvestris Ser, wild cherry fruits

\section{Material and Methods}

The vegetal product represented by the mature drupes, without seeds of the wild cherry fruits (Fig. 2), was collected from Romania, Dobrudjia area, Constanta county, in the period of July 2018 - July 2019. 
- Sample preparation: $0,5 \mathrm{~g}$, respectively $5 \mathrm{~g}$ of fresh vegetal product were extracted with $50 \mathrm{~mL}$ ethanol 40\%, 70\%, 96\% concentration, by cold maceration for 10 days. It was kept in the dark with periodic stirring. Extractive solution obtained was filtered on quantitative Whatman filter paper and $100 \mathrm{~mL}$ volumetric flask was filled in to the mark with ethanol sol. $40 \%, 70 \%$, respectively $96 \%$ concentration. Due to the increased values of concentration (TEAC), which exceed Trolox standard calibration curve, respectively the detection limit, for the working solution, all stock solutions of extracts were diluted with $50 \mathrm{~mL}$ of ethanol $40 \%$, 70\%, respectively $96 \%$ concentration, molar ratio 1:2. From the diluted solutions, were taken work volumes of $5 \mu \mathrm{L}$, for all samples.

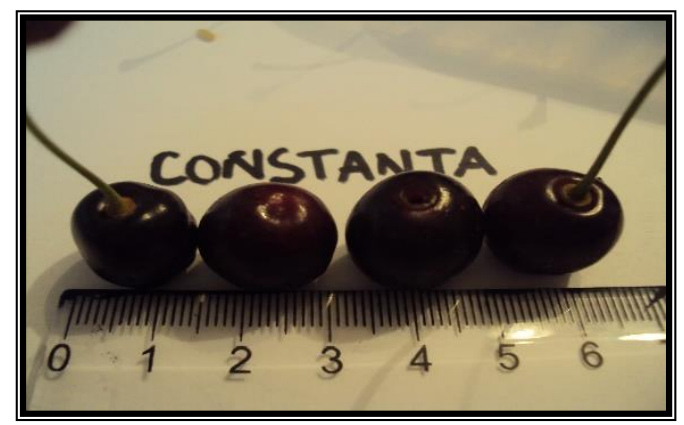

Figure. 2. Mature drupes wild cherry fruits

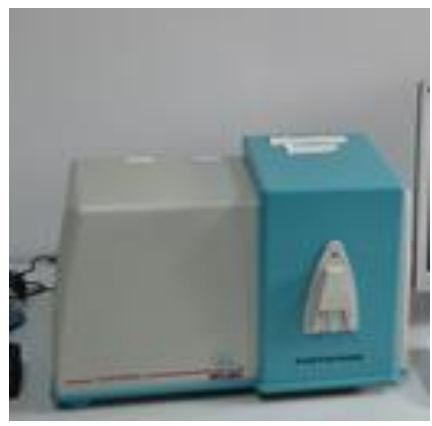

Figure. 3. Photochemiluminometer Photochem, Analytik Jena AG, Germany

\section{Antioxidant activity by photochemiluminescence method}

Evaluation of total antioxidant activity of hydro-alcoholic extract of Cerasus avium fruits was performed through photochemiluminescence method, determining the Antioxidant Capacity of Lipid soluble substances (ACL), according to Analitik Jena procedure, using photochemiluminometer PHOTOCHEM, Analytik Jena AG, Germany, coupled to a PC.

Total antioxidant activity was quantified by comparison with Trolox® standard solution, Hoffman-LaRoche's trade name for 6-hydroxy-2,5,7,8-tetramethylchroman2 -carboxylic acid, a water-soluble derivative of vitamin E. It is an antioxidant used in biological or biochemical applications to reduce oxidative stress or free radicals damage. External light source is mercury lamp covered with phosphorus, which ensure maximum power at $\lambda=351 \mathrm{~nm}$ and the source of free radicals is luminol (5amino-2, 3-dihydro-1,4-phthalazinedione). The measuring signal produced by the luminescence is traced over 120 sec., [38, 39].

Calibration curve of Trolox standard was done by measuring 4 solutions of $0.5,1.0$, 2.0, $3.0 \mathrm{nmol}$ of standard Trolox® (Fig. 4) and samples measurements (Fig. 5) were 
performed according to the standard protocol of the ACL method, Analytik Jena AG, using volumes according to the scheme below (Table 2).

Reagent $\mathrm{R}_{1}$ - methanol p.a.;

Reagent $\mathrm{R}_{2}$ - buffer solution;

Reagent $R_{3}$ - photosensitizing reagent and free radical detection reagent;

Reagent $\mathrm{R}_{4}$ - calibration standard (Trolox), for antioxidant quantification of lipidsoluble substances.

Table 2. Working procedure, Analytik Jena AG

\begin{tabular}{|c|c|c|c|c|c|}
\hline $\begin{array}{l}\text { Measuremen } \\
\mathrm{t}\end{array}$ & $\begin{array}{l}\text { Volum } \\
\text { reagent } \\
\mathrm{R}_{1} \\
(\mu \mathrm{L})\end{array}$ & $\begin{array}{l}\text { Volum } \\
\text { reagent } \\
\mathrm{R}_{2} \\
(\mu \mathrm{L})\end{array}$ & $\begin{array}{l}\text { Volum } \\
\text { reagent } \\
\mathrm{R}_{3} \\
(\mu \mathrm{L})\end{array}$ & $\begin{array}{l}\text { Volum reagent } \mathrm{R}_{4} \\
\text { Calibration curve } \\
(\mu \mathrm{L})\end{array}$ & $\begin{array}{l}\text { Volum } \\
\text { sample } \\
(\mu \mathrm{L})\end{array}$ \\
\hline Blank & 2.300 & \multirow{6}{*}{200} & \multirow{6}{*}{25} & 0 & 0 \\
\hline \multirow{4}{*}{$\begin{array}{l}\text { Calibration } \\
\text { curve }\end{array}$} & 2.295 & & & 5 & 0 \\
\hline & 2.290 & & & 10 & 0 \\
\hline & 2.280 & & & 20 & 0 \\
\hline & 2.270 & & & 30 & 0 \\
\hline $\begin{array}{l}\text { Samples } \\
\text { curve }\end{array}$ & 2.295 & & & 0 & 5 \\
\hline
\end{tabular}

The signal emitted by free radicals remaining in the sample which did not reacted with the antioxidants of the sample, was measured. This reaction occurs by emission of light quanta and registered by the detector (PMT). The voltage (V) is proportional with generate luminiscence in timp (s). Trolox equivalent antioxidant activity (TEAC) is a measurement of antioxidant strength, measured in units called Trolox Equivalents (TE), [nmol/sample], [38, 39].

Apparatus used: photochemiluminometer Photochem, Analytik Jena AG, Germany (Fig. 3). 


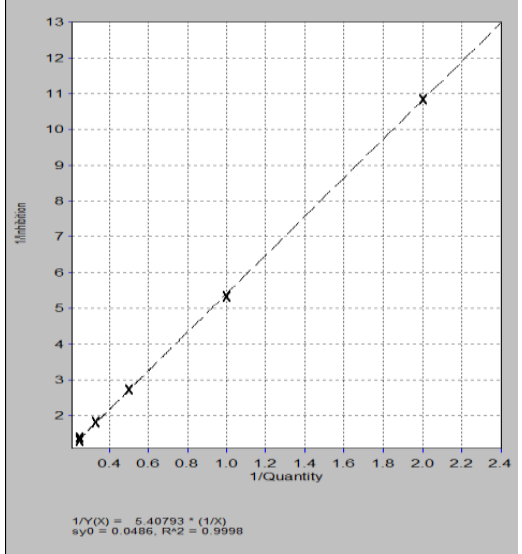

Figure 4. Trolox standard calibration curve

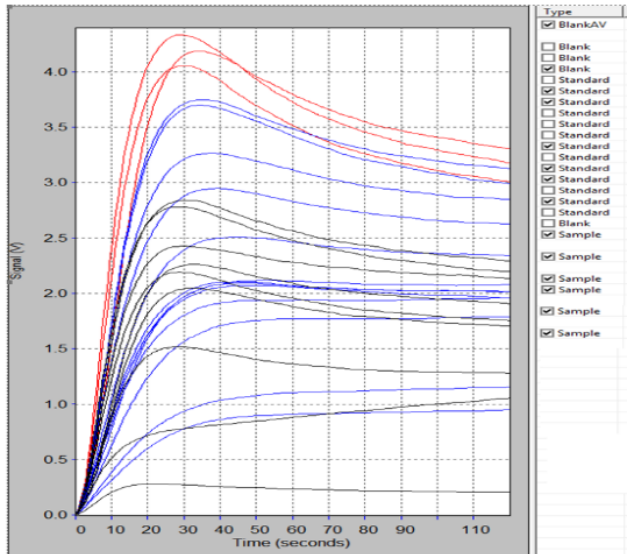

Figure 5. TEAC curves of blank, standards and samples

\section{Results and Discussion}

The results regarding the total antioxidative capacity (TEAC) of the wild cherry fruits fluid extracts, registered for the analyzed period, are presented in Table 2.

Table 2. Total antioxidant capacity (TEAC) of wild cherry fruits fluids extracts

\begin{tabular}{|c|c|c|c|c|}
\hline No. & Sample & $\begin{array}{l}\text { Free radicals } \\
\text { Max. } \\
\text { Inhibition }\end{array}$ & $\begin{array}{lr}\begin{array}{l}\text { Total } \\
\text { capacity }\end{array} & \text { antioxidant } \\
\text { ecquiv.Trolox/ } & \text { (nmol } \\
\text { sample) } & \text { vol. }\end{array}$ & $\begin{array}{l}\text { Concentration } \\
(\mu \mathrm{g} / \mathrm{mg})\end{array}$ \\
\hline 1. & $\begin{array}{l}\text { Extract } 1 \% \text { in } 40 \% \\
\text { ethanol, stock sol. }\end{array}$ & 0.846 & $\begin{array}{l}4.630 \\
\text { too high }\end{array}$ & $\begin{array}{l}\text { exceeds } \\
\text { calibration curve }\end{array}$ \\
\hline 2. & $\begin{array}{l}\text { Extract } 1 \% \text { in } 70 \% \\
\text { ethanol, stock sol. }\end{array}$ & 0.871 & $\begin{array}{l}4.683, \\
\text { too high }\end{array}$ & $\begin{array}{l}\text { exceeds } \\
\text { calibration curve }\end{array}$ \\
\hline 3. & $\begin{array}{l}\text { Extract } 1 \% \text { in } 96 \% \\
\text { ethanol, stock sol. }\end{array}$ & 0.893 & $\begin{array}{l}4.703, \\
\text { too high }\end{array}$ & $\begin{array}{l}\text { exceeds } \\
\text { calibration curve }\end{array}$ \\
\hline 4. & $\begin{array}{l}\text { Extract } 10 \% \text { in } \\
40 \% \text { ethanol, stock } \\
\text { sol. }\end{array}$ & 0.995 & $\begin{array}{l}4.898 \\
\text { too high }\end{array}$ & $\begin{array}{l}\text { exceeds } \\
\text { calibration curve }\end{array}$ \\
\hline 5. & $\begin{array}{l}\text { Extract } 10 \% \text { in } \\
70 \% \text { ethanol, stock } \\
\text { sol. }\end{array}$ & $>1$ & $\begin{array}{l}\text { Not registered } \\
\text { Over detection limit }\end{array}$ & $\begin{array}{ll}\text { Over } & \text { detection } \\
\text { limit } & \end{array}$ \\
\hline 6. & $\begin{array}{l}\text { Extract } 10 \% \text { in } \\
96 \% \text { ethanol, stock } \\
\text { sol. }\end{array}$ & $>1$ & $\begin{array}{l}\text { Not registered } \\
\text { Over detection limit }\end{array}$ & $\begin{array}{ll}\text { Over } & \text { detection } \\
\text { limit } & \end{array}$ \\
\hline 7. & $\begin{array}{l}\text { Extract } 1 \% \text { in } 40 \% \\
\text { ethanol, dil. } 1: 2\end{array}$ & 0.475 & 0,632 & 6,327 \\
\hline 8. & Extract $1 \%$ in $70 \%$ & 0.504 & 0,659 & 6,597 \\
\hline
\end{tabular}




\begin{tabular}{|l|l|l|l|l|}
\hline & ethanol, dil. 1:2 & & & \\
\hline 9. & $\begin{array}{l}\text { Extract 1\% in 96\% } \\
\text { ethanol, dil. 1:2 }\end{array}$ & 0.566 & 0.767 & 7,679 \\
\hline 10. & $\begin{array}{l}\text { Extract 10\% in } \\
40 \% \text { ethanol, dil. } \\
1: 2\end{array}$ & 0.517 & 6,748 \\
\hline 11. & $\begin{array}{l}\text { Extract 10\% in } 0.625 \\
70 \% \text { ethanol, dil. } \\
1: 2 \text { in } 0.638\end{array}$ & 0.785 & 7,859 \\
\hline 12. & $\begin{array}{l}\text { Extract 10\% in } \\
96 \% \text { ethanol, dil. } \\
1: 2\end{array}$ & 8,870 \\
\hline
\end{tabular}

The highest values of the total antioxidative capacity (TEAC) of wild cherry fruits alcoholic extract from fresh vegetal product at the concentration $10 \%$ in ethanol $96 \%$ was $0.886 \mathrm{nmol}$ equiv.Trolox/volum sample $(8,870 \mu \mathrm{g} / \mathrm{mg})$, respectively $0.767 \mathrm{nmol}$ equiv.Trolox/volum sample $(7,679 \mu \mathrm{g} / \mathrm{mg})$ at the concentration $1 \%$ in ethanol $96 \%$, were registered.

The decreased values of the total antioxidative capacity (TEAC) of wild cherry fruits alcoholic extract from fresh vegetal product at the concentration $10 \%$ in ethanol $40 \%$ was $0.674 \mathrm{nmol}$ equiv.Trolox/volum sample $(6,748 \mu \mathrm{g} / \mathrm{mg})$, respectively $0.632 \mathrm{nmol}$ equiv.Trolox/volum sample $(6,327 \mu \mathrm{g} / \mathrm{mg})$ at the concentration $1 \%$ in ethanol $40 \%$, were registered.

The results obtained regarding the total antioxidant capacity (TEAC) of wild cherry fruits alcoholic extract, recommend the extraction of soluble substances by cold maceration in ethyl alcohol of $96 \%$ or $70 \%$ concentrations, as an optimal method of extracting valuable antioxidant compounds, with pharmaceutical/nutraceutical potential aplications.

\section{Conclusion}

Up to now, the development of pharmaceutical formulations has remained restricted to individual chemical drugs, even the properties obtained by using an optimal mixture of bio-active compounds could be strongly influenced by the synergism appeared in the system. The increased total antioxidant capacity registered in the case of wild cherry fruits fluid extracts, sustain the possibility to use this valuable vegetal product as ethanolic extract in different concentration, for some new nutraceutical products obtaining.

\section{References}

[1] Aguerrebere, I.A., Rojas Molina, A., Oomah, B.D., \& Drover, J.C.G. Characteristics of Prunus serotina seed oil, Food Chemistry, 2011, 124, pp. 983-990. 
[2] Asanica, Gille E., Cepoiu N., Badulescu L., Hoza D., Studies Regarding Some Biochemical Compounds Involved in Cherry Biocompatibility, The Faculty of Horticulture Symposium of Scientific Communications, Ed. Ion Ionescu de la Brazi, Iassy, Horticulture Series, 2005, 1 (48), pp. 63-66.

[3] Budan, S., Grădinariu, G., Cireşul, Editura Ion Ionescu de la Brad, Iaşi, 2000.

[4] Corneanu M., Iurea E., Sîrbu S., Biological properties and fruit quality of sweet cherry (Prunus avium L.) cultivars from Romanian assortment, Agronomy Research, 2020, 18(4), pp. 2353-2364.

[5] Ferretti G., Bacchetti T., Belleggia A., Neri D., Cherry Antioxidants: From Farm to Table. Review, Molecules, 2010, 15, pp. 6993-7005.

[6] Flora Republicii Populare Romîne, vol. IV, Editura Academiei Populare Romîne, 1956, pp. 847-848, 853-854.

[7] Henning, W., Herrmann, K., Flavonol Glycosides of sweet cherries (Prunus avium L.) and sour cherries (Prunus cerasus L.), LebensmittelUntersuchung und Forschung, 1980, vol. 170, pp. 433-444.

[8] Henning, W., Herrmann, K., Flavonol Glycosides of sweet cherries (Prunus avium L.) and sour cherries (Prunus cerasus L.), LebensmittelUntersuchung und Forschung, vol. 170, 1980, pp. 433 - 444.

[9] Ibarra-Alvarado, C., Rojas, A., Mendoza, S., Bah, M., Gutiérrez, D. M., Hernández-Sandoval, L., \& Martínez, M. Vasoactive and antioxidant activities of plants used in Mexican traditional medicine for the treatment of cardiovascular diseases, Pharmaceutical Biology, 2010, 48(7), pp. 732739.

[10] Intriago-Baldeón, D. P., Torres, M. L., Arahana, V., \& Tobar, J., Evaluación de la variabilidad genética del capulí (Prunus serotina subsp. capuli) en tres provincias del Ecuador. Revista Ecuatoriana de Medicina y Ciencias Biológicas, 2013, 34, pp. 11-24.

[11] Jiménez, M., Castillo, I., Azuara, E., \& Beristain, C.I., Antioxidant and antimicrobial activity of capulin (Prunus serotina subsp capuli) extracts, Revista Mexicana de Ingeniería Química, 2011, 10(1), pp. 29-37.

[12] Karlidag H., Ercisli S., Sengul M., Tosun M., Physico-chemical diversity in fruits of wild-growing sweet cherries (Prunus avium Ehrh.), Biotechnol. Biotec. Eq. (2009), 23, pp.1325-1329.

[13] Lee, S. \& Wen, J. A phylogenetic analysis of Prunus and the Amygdaloideae (Rosaceae) using ITS sequences of nuclear ribosomal DNA. American Journal of Botany, 2001, 88(1), pp. 150-160.

[14] Luna-Vázquez, F. J., Ibarra-Alvarado, C., Rojas-Molina, A., Rojas-Molina, J. I., Yahia, E. M., Rivera-Pastrana, D. M., Rojas-Molina, A., \& Zavala-Sánchez, A. M., Nutraceutical value of black cherry Prunus serotina Ehrh. Fruits: antioxidant and antihypertensive properties, Molecules, 2013, 18, pp. 14597-14612.

[15] Melichacova S., Timoracka M., Bystricka J., Vollmannova A., Cery J., Relation of total antiradical activity and total polyphenol content of sweet cherries 
(Prunus avium L.) and tart cherries (Prunus cerasus L.), Acta Agriculturae Slovenica, 2010, 95 (1), pp. 21-28.

[16] Middleton, E. Jr, Kandaswami, Ch., The Flavonoids: Advances in Research, Ed. Chapman and Hall, London, 1993, p. $619-652$.

[17] Moldovan L., Gaspar A., Toma L., Craciunescu O., Saviuc C., Comparison of Polyphenolic Content and Antioxidant Capacity of Five Romanian Traditional Medicinal Plants, Rev. Chim., 2011, 62, (3), 299-303

[18] Negreanu-Pîrjol B., Negreanu-Pîrjol T., Bucur L., Popescu A., Paraschiv G.M., Sîrbu R., Meghea A., Antioxidative activity of Romanian Prunus Serotina Ehrh. (wild bitter cherry) fruit extract, Proceedings, International U.A.B B.En.A Conference, Environmental engineering and sustainable development, May 26-27th, 2011, Alba-Iulia, Romania, pp. 387-392.

[19] Negreanu-Pîrjol B., Popescu A., Bucur L., Negreanu-Pîrjol T., Arcuş M., Preliminary data regarding the study of some Prunus serotina Ehrh. fruits extract, Rev. Med. Chir. Soc. Med. Nat. of Iassy, 2009, 113, (2), Supplement No. 4, pp. 282-286.

[20] Negreanu-Pîrjol B.S., Negreanu-Pîrjol T., Bratu M.M., Roncea F., Mireşan H., Sanda J., Paraschiv G.M., Popescu A., Antioxidative activity of indigen bitter cherry fruits extract corellated with polyfenols and minerals content, $14^{\text {th }}$ International Multidisciplinary Scientific GeoConferences „Surveying Geology \& mining Ecology Management - SGEM 2014", 17 - 26 June 2014, Albena, Bulgaria, Conference Proceedings, Section: „Advances in Biotechnology", Vol. I, pp. 239 - 244.

[21] Negreanu-Pîrjol B.-S., Negreanu-Pîrjol T., Jurja S., Moise I., Lepădatu A.C., Comparative antimicrobial activity of some indigenous berries fruits extracts, $17^{\text {th }}$ International Multidisciplinary Scientific GeoConferences SGEM 2017 - Nano, Bio and Green - Technologies for a Sustainable Future", 29 June - 5 July 2017, Albena, Bulgaria, Conference Proceedings, Section „Micro and Nano technologies, Advances in Biotechnology”, Vol. 17, Issue 61 , pp. $569-576$.

[22] Negreanu-Pîrjol T., Negreanu-Pîrjol B.-S., Popescu A., Bratu M.M., Udrea M., Buşuricu F., Comparative Antioxidant Properties of some Romanian Foods Fruits Extracts, Journal of Environmental Protection and Ecology, 2014, vol. 15, no. 3, pp. $1139-1148$.

[23] Negreanu-Pirjol T., Roncea F. N., Negreanu-Pirjol B.-S., Niţu B., Jurja S., Antimicrobial and antioxidant activities of some mouthwashes based on black and red fluid fruits extracts, $16^{\text {th }}$ International Multidisciplinary Scientific GeoConferences - SGEM Vienna Green 2016 - Nano, Bio and Green - Technologies for a Sustainable Future, 2 - 5 November 2016, Vienna, Austria, Hofburg Congress Center, Extended Scientific Sessions, Conference Proceedings, Section „Advances in Biotechnology”, Vol. III, 23, pp. 177-184 
[24] Negreanu-Pîrjol T., Sîrbu R., Negreanu-Pîrjol B.-Ş., Antioxidant Activity of some Nutraceuticals based on Romanian Black and Red Fruits Mixed Extracts, 5th International Conference on Social Sciences - ICSS-2015, Pristina-Kosovo, 10-11 April 2015, Conference Proceedings, Vol. III, pp. $253-262$.

[25] Oancea S., Călin, F., Phenolics content, in vitro antioxidant and anticholinesterase activities of combined berry extracts, Romanian Biotechnological Letters, 2018, Vol. 23, No. 5, pp. 14025- 14034.

[26] Olszewska, M., Flavonoids from Prunus serotina Ehrh, Acta Polon. Pharm., 2005, 62, pp. 127-133.

[27] Olszewska, M., High-performance liquid chromatographic identification of flavonoid monoglycosides from Prunus serotina Ehrh, Acta Polon. Pharm., 2005, 62, pp. 435-441.

[28] Olszewska, M., Quantitative HPLC Analysis of flavonoids and chlorogenic acid in the leaves and inflorescences of Prunus Serotina Ehrh., Acta Chromatographica, 2007, no. 19, pp. 253-269.

[29] Ordaz-Galindo, A., Wesche-Ebeling, P., Wrolstad, R. E., Rodriguez-Saona, L., Argaiz-Jameta, A., Purification and identification of capulin anthocyanins, Food chemistry, 1999, vol. 65, pp. 201-206.

[30] Pârvu, C., Enciclopedia plantelor, vol. I, Editura Tehnică, Bucureşti, 2005, pp. 687-714, 733-737.

[31] Popov, I., Lewin, G., Antioxidative Homeostasis: Characterization by Means of Chemiluminescent Technique, Methods in Enzymology, vol. 300, Oxidants and Antioxidants, Part B, ed. Lester Packer, Academic Press, 1999, pp. 437-456.

[32] Popov, I., Lewin, G., Photochemiluminescent detection of antiradical activity; IV: Testing of lipid-soluble antioxidants, J. Biochem. Biophys, Methods, 1996, 31, pp. 1-8.

[33] Prvulović D., Popović M., Malenčić D. , Ljubojević M., Barać G., Ognjanov V., Phenolic content and antioxidant capacity of sweet and sour cherries, Studia UBB Chemia, LVII, 4, 2012, pp. 175-181.

[34] Radu, A., Botanica farmaceutica. Editura Didactică şi Pedagogică, București, 1974.

[35] Serrano M., Guillén F., Martínez-Romero D., Castillo S., Valero D., Chemical Constituents and Antioxidant Activity of Sweet Cherry at Different Ripening Stages, J. Agric. Food Chem. 2005, 53, 7, pp. 2741-2745.

[36] Simion, Florea Marian, Botanica Poporană Română, vol. I, Editura Muşatini, Suceava, 2008, pp. 468-472.

[37] Sirbu S., Oprica L., Poroch V., Iurea E., Corneanu M., Grigor M.N., Physical Parameters, Total Phenolics, Flavonoids and Vitamin C Content of Nine Sweet Cherry Cultivars, Revue Roumaine de Chimie, January 2018, 69(1), pp. 125-129. 
[38] T. Negreanu-Pîrjol, R. Sîrbu, B.-Ş. Negreanu-Pîrjol, Antioxidant activity of some nutraceuticals based on Romanian black and red fruits mixed extracts, Academic Journal of Interdisciplinary Studies, MCSER Publishing, Rome-Italy, Vol. 4, No. 1 S2, April 2015, pp. 199 - 206.

[39] Wagner, H., Bladt, D., Zgainski, E.M, Plant drug Anaysis, Springer-Verlag, Berlin, Heidelberg, New-York, Tokio, 1984. 